\title{
A macroeconomia do governo Médici (1969-1974): uma contribuição ao debate sobre as causas do "milagre" econômico
}

\author{
Victor Leonardo de Araujo ${ }^{1}$
}

\begin{abstract}
Resumo: Ao descrever a política macroeconômica do governo Médici (1969-1974), de cunho preponderantemente expansiva, este trabalho procura contribuir para a literatura a respeito das causas do assim chamado "milagre" econômico brasileiro. Este trabalho defende que a guinada heterodoxa - para a qual o governo Médici contribuiu dando continuidade e intensificando a política macro herdada de Costa e Silva, e aprimorando as instituições existentes para viabilizar a expansão - foi mais importante para explicar as elevadas taxas de crescimento do produto do que as reformas do governo Castello Branco.
\end{abstract}

Palavras-chave: Governo Médici, "Milagre" econômico, Ditadura militar.

\begin{abstract}
In describing the macroeconomic policy of the Medici government (19691974) as predominantly expansive, this paper aims to contribute to the literature on the causes of the so-called Brazilian economic "miracle". This work argues that the heterodox shift - to which the Medici government contributed by continuing and intensifying the macro policy inherited from Costa e Silva and improving existing institutions to make expansion feasible - was more important to explain the high rates of product growth than the Castello Branco government reforms.
\end{abstract}

Keywords: Médici government, Economic “miracle”, Military dictatorship.

Classificação JEL: N16, N36.

\footnotetext{
${ }^{1}$ Professor da Faculdade de Economia da UFF e coordenador do Núcleo de Pesquisas em Economia e Sociedade Brasileira (NEB). E-mail: victor_araujo@terra.com.br
} 


\section{Introdução}

O governo do Presidente Emílio Garrastazu Médici (1969-1974) coincide com o auge e o esgotamento do assim chamado "milagre econômico", período que compatibilizou altas taxas de crescimento do produto interno bruto (PIB) com inflação em queda, sem a ocorrência de crises cambiais.

A eleição de Médici e de seu vice, Almirante Augusto Rademaker, ocorreu de forma extemporânea, já que seu antecessor, General Arthur da Costa e Silva, adoeceu em agosto de 1969 e foi impossibilitado de terminar seu mandato presidencial - vindo a falecer em dezembro do mesmo ano - e os ministros militares impediram a posse de seu vice, Pedro Aleixo, um civil. A indicação do nome de Médici pelo alto comando do Exército para disputar as eleições indiretas daquele ano tinha o significado de continuidade com a gestão abruptamente interrompida: no plano político, a repressão aos movimentos políticos de esquerda - guerrilha, movimento estudantil, sindicatos - recrudescia; no plano econômico, a recuperação da atividade no biênio anterior contribuía com os objetivos de legitimar a ditadura junto ao empresariado e à classe média, embora a piora da distribuição de renda contribuísse para acirrar os ânimos oposicionistas.

Dessa forma, a tônica do novo governo seria a continuidade com o conjunto de políticas executadas pelo seu antecessor, especialmente no plano da política macroeconômica, com o anúncio da manutenção de Antonio Delfim Netto como titular do Ministério da Fazenda. Delfim era o artífice da nova política macroeconômica, que combinava expansão dos gastos do governo, do crédito e uma política de controle dos preços que, combinadas, asseguraram um desempenho macroeconômico inédito: a taxa de crescimento do produto havia se acelerado para $9 \%$ no biênio $1967-8$, e a inflação estava em queda, sem a ocorrência de crises cambiais. Segundo Skidmore (1988: 213), "[a manutenção de Delfim] na pasta da Fazenda significava a continuidade da aplicação de suas políticas econômicas tão bem-sucedidas (em termos de crescimento) e tão controvertidas (em termos de equidade social)". No Planejamento, João Paulo dos Reis Velloso substituiu Hélio Beltrão e anunciou o I Plano Nacional de Desenvolvimento, que articulava estímulos e diretrizes de ambiciosos investimentos setoriais. Em linha com o governo Costa e Silva, a gestão macroeconômica do governo Médici distanciou-se ainda mais daquela realizada durante o governo Castello Branco e obteve resultados superiores. Nos seis anos compreendidos entre 1968 e 1973, o PIB cresceu em média $11 \%$ a.a., a inflação caiu para 15\% em 1973, sem a ocorrência de crises cambiais que outrora interrompiam a expansão econômica. No governo Médici, o termo "milagre" passou a ser utilizado para caracterizar o período, à semelhança das experiências alemã, japonesa e sul-coreana, que também registraram taxas de crescimento bastante aceleradas durante a reconstrução de 
suas economias no pós-Segunda Guerra. Obviamente, o termo se circunscreveu ao desempenho macroeconômico, já que na área social se abateu um infortúnio: a renda se concentrou no topo da pirâmide social, o poder de compra dos salários foi corroído, e o padrão de vida das famílias mais pobres, medidos por diversos indicadores, piorou.

A hipótese deste trabalho é que a política macroeconômica - nas dimensões das políticas fiscal, financeira e de combate à inflação - do governo Médici possui fortes traços de continuidade com a de seu antecessor, sendo marcado por políticas de estímulo à demanda agregada, sobretudo nos campos fiscal e financeiro. Importantes modificações institucionais foram introduzidas com o intuito de favorecer o viés expansivo daquelas duas políticas, inclusive do ponto de vista operacional, aprofundando e intensificando o caráter heterodoxo dessas políticas e afastando-se cada vez mais do caráter mais ortodoxo que caracterizou o governo Castello. Este trabalho defende que o viés heterodoxo da política macroeconômica do governo Médici foi essencial para sustentar as altas taxas de crescimento em vigor desde o governo Costa e Silva. Este trabalho pretende contribuir para o debate a respeito das causas do "milagre" com elementos mais detalhados a respeito da política macroeconômica desempenhada durante esse período.

Depois dessa introdução, a segunda seção apresenta o panorama político do governo Médici, bem como suas diretrizes gerais. Na seção três, será discutida a política macroeconômica nas suas três esferas: a política fiscal, a política financeira e a política de combate à inflação. A seção quatro discutirá o desempenho do setor externo. Como é impossível falar do "milagre" sem discutir a piora da distribuição de renda ocorrida desde a década de 1960, a seção cinco descreverá os dados e o debate. A seção seis fará as considerações finais.

\section{O panorama do período}

A escolha do General Emilio Garrastazu Médici como candidato oficial à vaga deixada por Costa e Silva esteve longe de ser um processo consensual no interior das forças armadas brasileiras. O governo Costa e Silva havia sido abruptamente interrompido por um problema grave de saúde que lhe acometeu, e seu vice, Pedro Aleixo, um civil, foi impedido de assumir a Presidência da República pelos ministros militares. Enquanto a sucessão era tramada e o país era governado por uma junta militar, um grupo de oposição armada sequestrara o embaixador dos Estados Unidos no Brasil, Charles Elbrick, exigindo a libertação de 15 presos políticos. O pedido fora atendido, mas o regime endureceria. Pela primeira vez, a sucessão presidencial era precedida de uma consulta ao oficialato das forças armadas. O general Albuquerque Lima, nacionalista e defensor de um maior endurecimento do regime, tinha a preferência dos oficiais, mas como a sua 
candidatura não assegurava a continuidade dos "rumos da revolução", a junta militar o desqualificou alegando possuir apenas três estrelas - artifício utilizado para restringir a escolha aos generais de quatro estrelas, e induzir a escolha para o nome de Médici, apontado pelo oficialato como capaz de unificar os sentimentos divergentes no interior das três forças.

Escolhido e eleito, Médici foi empossado em 30/10/1969. No plano político, seu governo foi marcado pela repressão à luta armada contra a ditadura militar, sendo representativas as mortes de Carlos Marighela e de Carlos Lamarca, cujos corpos foram encontrados, respectivamente, em novembro de 1969 e em setembro de 1971. Mesmo sob os auspícios do autoritarismo do Ato Institucional no 5, Médici manteve as eleições indiretas para os poderes legislativos em todos os níveis, não sem antes promover modificações na legislação eleitoral. A primeira delas foi o descasamento do calendário eleitoral, para evitar a coincidência das eleições municipais com as eleições para os legislativos estaduais, Câmara dos Deputados e Senado. O número de cadeiras na Câmara dos Deputados foi reduzido de 409 para 310, e a base de cálculo para a representação parlamentar passaria a ser calculada segundo o número de eleitores registrados, e não segundo a população total. Como nas regiões Norte e Nordeste a taxa de analfabetismo era superior às demais regiões, e o código eleitoral brasileiro impedia o registro eleitoral de analfabetos, o novo esquema elevaria a representatividade dos estados do Centro-Sul. Nas eleições de 1970, na qual 2/3 do Senado seriam renovados, o MDB elegeu apenas 6 senadores, contra 4o da ARENA (SKIDMORE, 1988).

Na economia, o governo Médici manteria Delfim Netto no Ministério da Fazenda, e no Planejamento substituiria Helio Beltrão por João Paulo dos Reis Velloso. O início do governo Médici seria marcado pela continuidade, tendo ainda como peça central de suas diretrizes o Programa Estratégico de Desenvolvimento (PED), ainda em vigor, mas em setembro de 1971 o governo anunciaria o I Plano Nacional de Desenvolvimento. Se a política macroeconômica do período 1967-70 havia sido exitosa em reduzir a capacidade ociosa, agora a expansão da capacidade seria condição para a manutenção das vigorosas taxas de crescimento que, a essa altura, já caracterizavam o "milagre" brasileiro.

A partir da constatação de que "tudo se tornou maior no Brasil", o I PND tinha objetivos ambiciosos: colocar o Brasil no rol das economias desenvolvidas ao tempo de uma geração; duplicar a renda per capta até 1980; e garantir a geração de empregos, mantendo elevado o crescimento do PIB e compatibilizando-o com a estabilidade de preços, sob a meta de inflação de $10 \%$ no último ano do governo Médici (BRASIL, PRESIDÊNCIA DA REPÚBLICA, 1971).

A inovação tecnológica para aumento da produtividade e competitividade internacional constituiria as diretrizes do I PND no tocante ao setor produtivo. Para assegurar transferência e aquisição de tecnologia, o Plano previa 
investimentos em pesquisa nas áreas de energia elétrica, tecnologia nuclear, petróleo, comunicações, siderurgia, pesquisa mineral e pesquisa espacial. A consolidação da infraestrutura econômica e das indústrias básicas exigiriam investimentos pesados, e os grandes programas de investimento eram: o Programa de Expansão em Siderurgia; Programa Petroquímico; Implantação de Corredores de Transportes; Programa de Construção Naval; Programa Básico de Energia Elétrica - que incluiria a primeira central nuclear do País; Programa de Comunicações - com o objetivo de um milhão de linhas telefônicas; e Programa de Minerações.

O Plano inovava em um aspecto. Delfim estava ciente de que o mercado interno brasileiro tinha dimensões limitadas para uma estratégia de desenvolvimento que nele se amparasse. Por outro lado, o pacto político que emergia da deposição do governo João Goulart rechaçava qualquer possibilidade de expandir o mercado interno por meio de reformas distributivas. O setor externo seria a variável capaz de equilibrar a equação: em vez de meramente complementar, a demanda externa passaria a exercer papel de maior protagonismo no modelo de desenvolvimento brasileiro, alavancando parte da demanda agregada total. Por outro lado, taxas ambiciosas de crescimento do produto provocariam expansão acelerada das importações e era necessário antecipar-se ao crônico problema da restrição externa, preferencialmente por meio do crescimento das exportações. O equilíbrio do setor externo requeria, portanto, o estímulo às exportações. Em razão das limitações impostas pela baixa competitividade da produção industrial doméstica, dois tipos de esforços seriam empreendidos. $\mathrm{O}$ primeiro, na forma de isenções fiscais à indústria manufatureira exportadora, envolvendo impostos federais - como o IPI, IR sobre o lucro - e estaduais - como o ICM para empresas exportadoras. O segundo foi na forma do estímulo às exportações do setor agropecuário, naquilo que Macarini (2005) caracterizou como o modelo "agrícola-exportador". A partir de um diagnóstico que sugeria que a industrialização substitutiva de importações teria gerado uma indústria ineficiente e dependente dos esquemas de proteção, e um longo período de tempo requerido para superar tal quadro, os investimentos necessários para estimular as exportações teriam de ser multissetoriais. Com efeito, embora a indústria continuasse a receber toda a sorte de incentivos, agora estes também seriam direcionados à agropecuária. Nesse setor, especificamente, recairiam as expectativas de aumento das exportações naquilo que caracterizaria um modelo "agrícola-exportador". Assim, enquanto o I PND estipulava como meta expandir a indústria à taxa de 10 a $12 \%$ anuais, a meta para o setor primário era de 7 a $8 \%$ anuais, pouco inferior à meta de expansão do PIB, de 8 a 10\% anuais. (BRASIL, PRESIDÊNCIA DA REPÚBLICA, 1971) 
Grandes obras públicas seriam iniciadas por todo o território brasileiro e desafiavam a engenharia nacional, sendo os exemplos mais notórios: as rodovias Transamazônica e Cuiabá-Santarém, na região Norte, anunciadas como grandes obras de integração nacional; e aquela que até então seria a maior ponte do mundo, que sobre a Baía de Guanabara ligaria o município de Niterói ao Rio de Janeiro, no Sudeste. Ainda no último ano do governo Médici, seriam concluídas as tratativas para o início das obras da usina hidrelétrica binacional de Itaipu.

Ao término do governo Médici, o produto interno bruto (PIB) havia crescido à média de $11,9 \%$ anuais, capitaneada pela indústria de transformação, que cresceu $13 \%$ anuais; a inflação caía sistematicamente, até atingir $15 \%$ no último ano de seu mandato, algo impensável na década anterior. Contudo, o poder de compra do salário mínimo atingia o seu pior momento, equivalendo a apenas $68 \%$ do seu poder de compra de 1960 (tabela 1).

Tabela 1 - Brasil: indicadores macroeconômicos selecionados

\begin{tabular}{c|c|c|c|c|c}
\hline & PIB (taxa de & & $\begin{array}{c}\text { Indústria de } \\
\text { cresc. \%) } \\
\text { Investi- } \\
\text { transformação, } \\
\text { taxa de } \\
\text { PIB) } \\
\text { crescimento } \\
\text { anual (\%) }\end{array}$ & $\begin{array}{c}\text { Inflação IGP- } \\
\text { DI (\%) }\end{array}$ & $\begin{array}{c}\text { Salário mínimo real, } \\
\text { indice (1960 = } \\
100)\end{array}$ \\
\hline 1967 & 4,2 & 16,2 & 2,2 & 25,0 & 72,04 \\
\hline 1968 & 9,8 & 18,7 & 14,2 & 25,5 & 72,11 \\
\hline 1969 & 9,5 & 19,1 & 11,2 & 19,3 & 69,10 \\
\hline 1970 & 10,4 & 18,8 & 11,9 & 19,2 & 68,00 \\
\hline 1971 & 11,3 & 19,9 & 11,9 & 19,5 & 67,99 \\
\hline 1972 & 11,9 & 20,3 & 14,0 & 15,7 & 68,26 \\
\hline 1973 & 7,8 & 20,4 & 16,6 & 15,5 & 69,65 \\
\hline $1970-1973$ & 11,9 & 18,0 & 9,08 & 23,2 & 71,1 \\
\hline
\end{tabular}

Fonte: Ipeadata e IBGE (Estatísticas Históricas do Século XX), elaboração própria.

\section{A política macroeconômica}

\subsection{A política fiscal}

A política fiscal do governo Médici seguiu a diretriz básica de seu antecessor e consistiu essencialmente na combinação de desonerações fiscais com expansão do gasto. Segundo os dados de execução orçamentária do Tesouro Nacional fornecidos pelo Banco Central do Brasil, o gasto público da União cresceu a taxas crescentes durante todo o governo Médici, à média anual de $16 \%$ acima da inflação (tabela 2). O governo Médici também fez uso das dilatações dos prazos para 
recolhimento dos impostos indiretos federais para setores como o de indústrias têxteis, de calçados e de aço (MACARINI 2005).

O governo Médici constituiu um perfeito laboratório para atestar a validade do princípio da demanda efetiva: o crescimento do gasto público, combinado com outras políticas expansionistas, como a monetária (conforme veremos mais adiante), proporcionou a aceleração das taxas de crescimento do PIB, e a arrecadação tributária respondeu, crescendo também a taxas crescentes, tendo atingido a média de $18 \%$ a.a. em termos reais. A arrecadação registrou forte crescimento a despeito da pesada política de desonerações iniciada no governo Costa e Silva e mantida durante os anos Médici. Com efeito, o déficit público registrou forte queda em todo o período, e a execução orçamentária do último ano do governo Médici encerrou com um pequeno superávit.

Tabela 2 - Indicadores selecionados de finanças públicas, 1967-1974

\begin{tabular}{|c|c|c|c|c|c|c|c|c|c|}
\hline & 1967 & 1968 & 1969 & 1970 & 1971 & 1972 & 1973 & $67-69$ & $70-73$ \\
\hline \multicolumn{10}{|c|}{ Execução orçamentária do Tesouro Nacional, taxa de crescimento real, \% (2) } \\
\hline Receita & $-9,64$ & 21,20 & 14,02 & 14,37 & 17,04 & 19,91 & 21,89 & 7,68 & 18,27 \\
\hline Despesa & $-2,03$ & 14,73 & 6,63 & 12,62 & 15,31 & 18,53 & 19,84 & 6,22 & 16,54 \\
\hline \multicolumn{10}{|c|}{ Resultado fiscal (Cr\$ bilhões de 1974) } \\
\hline & $-5,2$ & $-4,2$ & $-1,9$ & $-1,6$ & $-1,1$ & $-0,5$ & 0,6 & $-3,7$ & $-2,5$ \\
\hline \multicolumn{10}{|c|}{ Carga tributária, \% do PIB (1) } \\
\hline Total & 21,62 & 24,30 & 25,91 & 25,98 & 25,26 & 26,01 & 25,05 & 23,94 & 25,58 \\
\hline Federal & 13,72 & 15,48 & 16,96 & 17,33 & 17,36 & 18,12 & 17,82 & 15,37 & 17,66 \\
\hline
\end{tabular}

Fonte: IBGE/Estatísticas Históricas do Século XX, Contas Nacionais. (2) Fonte: Banco Central do Brasil, Relatórios Anuais.

À margem do sistema tributário passaram a se integrar, desde o governo Castello, as chamadas contribuições parafiscais, destinadas ao financiamento de políticas sociais (OLIVEIRA, 2013), como o Fundo de Garantia por Tempo de Serviço (FGTS). Antes de completar um ano, o governo Médici criou o Programa de Integração Social (PIS), um fundo constituído a partir de contribuições recolhidas sobre o faturamento mensal das empresas privadas ${ }^{2}$ e que teria como cotistas os trabalhadores listados pelas próprias empresas. A participação de cada trabalhador no fundo seria calculada segundo critérios que levassem em consideração o seu

\footnotetext{
${ }^{2}$ Os percentuais seriam os seguintes: 0,15\% em 1971; o,25\% em 1972; 0,40\% em 1973; e 0,50\% a partir de 1974. Além disso, também constituiriam os recursos do PIS uma parcela referente à dedução do imposto de renda devido pelas empresas: $2 \%$ em 1971; $3 \%$ em 1972; e $5 \%$ depois de 1973. (LOLOYAN, 1980)
} 
salário médio e o tempo de trabalho na empresa. Individualmente, os trabalhadores poderiam sacar todos os anos o valor correspondente à remuneração do fundo, equivalente à correção monetária mais juros de 3\% ao ano; em casos de invalidez, aposentadoria, casamento ou aquisição de casa própria, poderiam sacar o valor integral. O caráter de "integração social" estaria associado à possibilidade de complementar a renda anual do trabalhador e permitir a formação de um patrimônio sob as condições específicas que lhe asseguravam o saque do principal. Contudo, como essas condições eram bastante restritivas, na prática os recursos se acumulariam e constituiriam fonte de recursos para que a Caixa Econômica Federal (CEF), instituição responsável pelos depósitos e pela gestão do fundo, pudesse expandir suas operações a partir de um funding barato e estável, que financiaria o capital de giro das empresas e outros projetos específicos definidos pelo governo.

Como o PIS era voltado apenas para os trabalhadores da iniciativa privada, o governo anunciou também a criação do Programa de Formação do Patrimônio do Servidor Público (Pasep). Sua função seria equivalente à do PIS, porém voltado para os servidores públicos dos três níveis de governo e das empresas estatais. Seria composto pela contribuição de um percentual da arrecadação da União, dos estados, dos territórios, do Distrito Federal e dos municípios. ${ }^{3}$ Os recursos do Pasep seriam depositados no Banco do Brasil (BB), e, à semelhança do PIS, constituiriam fontes de recursos para financiamento.

Do ponto de vista da carga tributária, somente o PIS significaria recursos adicionais, já que o Pasep constituiria apenas a reserva de uma parte da arrecadação da União e de seus entes federados. Contudo, as empresas privadas foram compensadas com novas desonerações fiscais na base de arrecadação do PIS, de modo que, na prática, o PIS foi inteiramente composto por recursos públicos. (OLIVEIRA, 2013; LOLOYAN, 1980)

O movimento iniciado com as reformas do governo Castello viabilizou um padrão institucional, que dali para adiante, seria fortemente centralizador. Primeiro, porque a reforma tributária centralizou a arrecadação em torno da União, reduzindo a capacidade de instituir tributos por parte dos estados e municípios. Com efeito, em 1973, a União concentrava $71 \%$ da arrecadação de impostos, cinco pontos percentuais acima dos 66\% arrecadados em 1970, ou onze pontos percentuais acima dos 6o\% obtidos em 1964 .

\footnotetext{
${ }^{3} \mathrm{O}$ percentual referente à contribuição da União na formação do Pasep seria calculado a partir da receita total, deduzidas as transferências às outras esferas da administração pública, nos seguintes percentuais: $1 \%$ a partir de 1/7/1970; 1,5\% em 1972; e $2 \%$ a partir de 1973. Os demais entes federativos contribuiriam com os mesmos percentuais calculados a partir das receitas próprias deduzidas as transferências; e com $2 \%$ sobre o total das transferências da União a título do fundo de participação, a partir de julho de 1971. (LOLOYAN, 1980)
} 
Segundo, porque a criação de fundos parafiscais como o FGTS, o PIS e o Pasep, respectivamente sob a gestão do Banco Nacional de Habitação (BNH), CEF e BB, dotavam as agências financeiras federais de forte capacidade de atuação. Sob a hierarquia do poder executivo e de seus ministérios, esses recursos poderiam ser alocados discricionariamente conforme as diretrizes da política econômica formuladas pelo governo federal. Os governos estaduais e municipais, financeiramente fragilizados depois da reforma tributária, se submeteriam aos desígnios do governo federal para acessar os recursos adicionais.

Finalmente, o governo Médici, por meio da Lei Complementar no 12, de o8/11/1971, retirou do Congresso Nacional o poder de legislar em matéria financeira, transferindo para o CMN a prerrogativa de tomar decisões sobre as operações de rolagem da dívida pública interna, incluindo seus encargos, bem como as demais operações de crédito destinadas a equilibrar a execução orçamentária. Na prática, o Orçamento Geral da União tornou-se figura de retórica, porque a ocorrência de déficits fiscais seria financiada por emissão de dívida, sobre a qual o Congresso Nacional não mais exercia qualquer controle. Além disso, parte dos gastos seria executada por meio do assim chamado orçamento monetário, que figuraria ao lado do orçamento fiscal como uma peça por meio da qual diversos projetos seriam financiados, sob decisões centralizadas no CMN (LOPREATO 2002). O orçamento monetário era elaborado pelo Banco Central e aprovado pelo CMN, e nele eram definidos os tetos das operações de empréstimos do BB, que, excedendo os volumes de captação de recursos junto ao público, eram supridos por meio da conta-movimento. ${ }^{4}$ (HORTA 1981)

$\mathrm{Na}$ prática, parte dos gastos do Tesouro era executada por meio do orçamento monetário - em vez do orçamento fiscal - e sancionada por uma combinação de expansão de base monetária e de dívida pública, sobre a qual também não havia controle legislativo. Segundo Corazza (2006: 8): "Uma verdadeira cortina de fumaça passava a encobrir as conexões entre o Tesouro, o Banco do Brasil e o Bacen."

Sob tal aspecto, pode-se dizer que a redução do déficit público a partir do final da década de 196o e sua gradual conversão em superávit em 1973, apresentada na tabela 2, não reflete as reais condições da política fiscal. Isso também significa que os dados da tabela 2 subestimam os reais efeitos da política fiscal sobre a demanda agregada.

Sob uma ótica keynesiana, e sob a aceitação do princípio da demanda efetiva, a expansão do consumo das famílias, do gasto do governo e das exportações tem impacto positivo sobre o nível de renda (efeito crowding-in). No que toca

\footnotetext{
${ }^{4}$ A conta-movimento garantia ao BB nivelamento automático do nível de suas reservas bancárias junto ao Banco Central, a taxas de juros bastante inferiores às de mercado. (COSTA 2012, BANCO DO BRASIL 2010)
} 
especificamente à política fiscal, o gasto governamental amplia a renda não só pela magnitude do próprio gasto, mas também por meio do efeito multiplicador, que reflete as influências do gasto inicial e de seus efeitos de encadeamento, descontados os "vazamentos" para a poupança, os impostos e as importações. Algumas modalidades de gasto possuem maior efeito multiplicador, como aqueles destinados a setores trabalho-intensivos, ou com maiores elos sobre a cadeia produtiva, como os gastos sociais, alguns gastos com custeio e os investimentos. Por outro lado, outras modalidades, como as despesas financeiras, têm efeitos de encadeamento menores ou nulos, porque em geral destinam-se a classes sociais de menor propensão marginal e média a consumir, e possivelmente serão preponderantemente poupados, sendo retirados do fluxo circular de renda (efeito crowding-out). Do ponto de vista keynesiano, o caráter expansivo da política fiscal não é medido pela ocorrência de déficits ou superávits fiscais, mas sim pela expansão dos gastos, especialmente daqueles de maior multiplicador. O resultado orçamentário é consequência dos efeitos da política fiscal e de seu efeito multiplicador sobre a renda, que, ao se expandir, elevará também a arrecadação total, para uma dada carga tributária. A composição da carga tributária, por sua vez, tem a capacidade de amplificar os efeitos do gasto inicial, caso recaia preponderantemente sobre as camadas de rendas com menor propensão a consumir. ${ }^{5}$ Nesse sentido, o caráter expansivo da política fiscal durante o governo Médici deve ser lido não pela transição de um déficit para um superávit na execução orçamentária do último ano de seu governo, mas sim pela expansão sistemática do gasto.

A existência de dois orçamentos a partir das reformas do governo Castello um fiscal e outro monetário - certamente dificultou o acompanhamento da execução orçamentária por não explicitar gastos que deveriam constar do orçamento fiscal. Mas foi a partir da Lei Complementar no ${ }^{12}$, que ampliou os poderes do CMN, que o orçamento monetário foi inflado. A falta de transparência, de acompanhamento social e legislativo do orçamento monetário desnudam o caráter autoritário do regime militar brasileiro, e permitem constatar a inadequação desse padrão institucional às boas práticas democráticas, o que não deve causar surpresa, por tratar-se de uma ditadura. Por outro lado, feitas essas ressalvas, o leitor não terá dificuldades de perceber que os dados da tabela 2 subestimam os efeitos expansivos da política fiscal desse período, já que parte dos gastos era executada por meio do orçamento monetário. Do ponto de vista de uma análise que procura captar os efeitos expansivos da política de gastos, o que se pode concluir é que foi gestada uma estrutura institucional que, se por um lado era

\footnotetext{
${ }^{5}$ Gentil \& Hermann (2015) apresentam uma boa síntese dos efeitos da política fiscal sob uma ótica keynesiana. Recomenda-se também: Carvalho (1999 e 2008), Gobetti (2008), além, obviamente, de Keynes (1936 [1996]).
} 
pouco transparente, por outro permitiu a execução de políticas cujo caráter expansionista não pode ser exclusivamente lido pelos dados de execução orçamentária.

\subsection{A política financeira}

No governo Médici, a política de tabelamento de juros, introduzida durante o governo Costa e Silva, assumiu outro patamar. Inicialmente, a política de teto para as taxas de juros das operações ativas foi configurada sob forma de adesão voluntária das instituições bancárias que quisessem obter outros benefícios, como a abertura de novas agências ou a manutenção de reservas remuneradas. Ou seja, se a instituição bancária desejasse obter algum daqueles benefícios, deveria limitar as taxas de juros de suas operações ativas àquelas definidas pelo Banco Central por meio de suas resoluções, mas a adesão não era compulsória (ARAUJO, 2017). A partir de fevereiro de 1970, o Banco Central simplesmente passou a definir as taxas, em caráter compulsório, distinguindo apenas o destino dos recursos. Assim, a Resolução no 134 do Bacen, de 18/2/1970, fixou as taxas em 1,6\% a.m. para as operações até 60 dias, e em 1,8\% a.m. para as de prazo superior, destinadas ao setor produtivo. Essas taxas foram gradualmente reduzidas em fevereiro de 1972 (para $1,4 \%$ e 1,6\% a.m., respectivamente, segundo a Resolução no207, de 2/2/1972) e em janeiro de 1973 (1,3\% a.m. e 1,4\% a.m., segundo a Resolução no.242, de 16/1/73). As taxas para operações destinadas a pessoas físicas somente foram tabeladas em fevereiro de 1972 , no limite de $2,5 \%$ a.m., e reduzidas para $2,3 \%$ a.m. em $1973 .^{6}$

Os percentuais referentes aos depósitos compulsórios não foram modificados com relação àqueles herdados do governo Costa e Silva, exceto os percentuais referentes aos depósitos a prazo, que foram zerados a partir de janeiro de 1973. Em março de 1970, o percentual máximo dos depósitos remunerados foi elevado de $40 \%$ para $55 \%$ (BCB, 1974). A autorização para manutenção de depósitos remunerados permitiu às instituições bancárias reduzir seus custos, compensando as possíveis perdas de margens de lucro com a fixação de taxas de juros. É bem verdade que as instituições bancárias conseguiam escapar dos juros fixados pelo Banco Central exigindo que os tomadores realizassem depósitos equivalentes a algum percentual do montante tomado - a exigência de reciprocidade. Na prática, a taxa efetiva era superior à tabelada pelo Banco Central.

A política de tabelamento de juros favoreceu a ocorrência de um processo de concentração bancária, já que as instituições maiores dispunham de melhores condições de mercado para impor a reciprocidade, e por isso suas taxas efetivas

\footnotetext{
${ }^{6} \mathrm{~A}$ taxa mais alta, de 1,8\% a.m., equivale a $23,9 \%$ a.a., enquanto a taxa mais baixa, de 1,3\% a.m., equivale a 16,8\% a.a. Em 1970, a inflação medida pelo IGP-DI foi de 19,3\%, e em 1973 foi de 15,5\%
} 
eram superiores às dos bancos de menor porte. Estes, por sua vez, também tinham dificuldade em obter ganhos com a escala, já que a política financeira estimulava a expansão das operações de crédito, e os bancos maiores tinham melhores condições de responder a esses estímulos. Além do tabelamento de juros, políticas mais restritivas à expansão da rede de agências também contribuíram para o processo de concentração. Para Lago (1990), esse processo de concentração foi muito mais decorrente da política econômica em seu conjunto, enquanto para Macarini (2007) foi parte integrante da estratégia assumida pela equipe econômica, não só para elevar a eficiência e reduzir os custos de operação do setor, "como subproduto das economias de escala decorrentes da concentração" (p. 354), mas também - e principalmente - como parte de uma estratégia de lançar as bases para um futuro projeto de maior integração entre os setores financeiro e industrial, à semelhança dos modelos japonês e alemão, mas na contramão da própria reforma financeira do governo Castello, baseada no segmentado modelo norte-americano. Em 1973, último ano do governo Médici, havia 115 estabelecimentos bancários em operação, dos quais 79 eram bancos privados nacionais; em 1969, eram 200 estabelecimentos ao todo, dos quais 164 eram privados nacionais (BRASIL, BANCO CENTRAL DO BRASIL, 1974). Segundo Macarini (2007), citando Silva (1980)7 e Portocarrero de Castro (1981), ${ }^{8}$ em 1967 os cinco maiores bancos privados detinham 20,9\% dos depósitos totais do sistema (excluindo o BB), passando para 34,2\% em 1976.

Com efeito, o crédito bancário ampliou a taxas crescentes durante todo o governo Médici (tabela 3), perfazendo a média anual de $20 \%$ a.a., superior aos $12 \%$ do governo Costa e Silva. O subconjunto representado pelos bancos comerciais e múltiplos liderou esse processo, expandindo suas operações à média anual de $20 \%$ a.a., superior aos $14 \%$ anuais de expansão das operações a partir do BB. Ao término do ano de 1973, o saldo das operações de crédito por meio dos bancos comerciais equivalia a $15,7 \%$ do PIB, contra $7,9 \%$ do BB e $3,5 \%$ das caixas econômicas (tabela 4).

${ }^{7}$ SILVA, A. M. (1980) Intermediação financeira. São Paulo: FIPE/USP. Mimeografado.

${ }^{8}$ PORTOCARRERO DE CASTRO, H. O. (1981). As causas econômicas da concentração bancária. Rio de Janeiro: IBMEC. 
Tabela 3 - Empréstimos bancários, taxa de crescimento real (\%)

\begin{tabular}{c|c|c|c|c}
\hline & $\begin{array}{c}\text { Bancos Comerciais e } \\
\text { Múltiplos }\end{array}$ & Banco do Brasil & Caixas Econômicas & Total \\
\hline 1967 & 32,5 & $-2,2$ & $\mathrm{Nd}$ & 11,7 \\
1968 & 25,6 & $-15,5$ & $\mathrm{Nd}$ & 11,4 \\
1969 & 19,9 & 0,8 & 22,7 & 12,5 \\
1970 & 13,1 & 3,0 & 57,6 & 12,7 \\
1971 & 19,9 & 5,6 & 26,1 & 15,8 \\
1972 & 25,7 & 22,9 & 32,7 & 25,6 \\
1973 & 24,1 & 28,3 & 41,2 & 27,3 \\
\hline $1964-66$ & 3,8 & 2,0 & $\mathrm{Nd}$ & 2,7 \\
$1967-69$ & 25,9 & $-5,9$ & $\mathrm{Nd}$ & 11,9 \\
$1970-73$ & 20,6 & 14,4 & 38,9 & 20,2 \\
\hline
\end{tabular}

Fonte: IBGE/Estatísticas Históricas do Século XX. Deflacionado pelo IGP-DI. Elaboração própria.

$\mathrm{Nd}=$ não disponível

Se por um lado a oferta de crédito foi estimulada pelo governo, por outro, o ambiente macroeconômico contribuía para que os elementos que compunham a demanda por crédito também entrassem em operação. As decisões de produção e de ampliação da capacidade produtiva induziam a maior demanda por crédito, embora muitas delas não fossem necessariamente atendidas pelos bancos comerciais, mas sim pelo sistema financeiro não monetário: o Banco Nacional de Habitação (BNH) e o Banco Nacional de Desenvolvimento Econômico (BNDE) também expandiram suas operações - o primeiro, viabilizando o financiamento à construção civil, notadamente voltado para sustentar a política habitacional da ditadura militar; e o segundo, voltado para o financiamento da formação bruta de capital. Durante o regime militar, o BNDE guinava em seu projeto histórico, tornando-se agora um banco eminentemente voltado para o financiamento do setor privado, especialmente o setor de siderurgia, cuja ampliação da capacidade constava dos ambiciosos objetivos do governo. A expansão das atividades do BNDE veio acompanhada do surgimento de uma profusão de instituições congêneres a ele, só que administrados pelos governos estaduais: em 1970 seriam criados bancos de desenvolvimento nos estados do Maranhão, Ceará, São Paulo e Rio Grande do Norte, somando-se a outros cinco bancos de desenvolvimento já existentes (CINTRA, 2009). Ao término de 1973, o saldo das operações de financiamento do BNDE equivalia a $2,4 \%$ do PIB, contra $0,77 \%$ no ano de 1968 . No mesmo período, o estoque das operações de crédito realizadas pelos bancos estaduais havia passado de $0,2 \%$ do PIB para $0,7 \%$ (tabela 4 ). 
Tabela 4 - Operações de crédito como \% do PIB 9

\begin{tabular}{c|c|c|c|c|c|c|c}
\hline & $\begin{array}{c}\text { Bancos } \\
\text { comerciais } \\
\text { e múltiplos }\end{array}$ & BB & $\begin{array}{c}\text { Caixas } \\
\text { econômicas }\end{array}$ & BNDE & $\begin{array}{c}\text { Bancos } \\
\text { estaduais de } \\
\text { desenv. }\end{array}$ & BNH & $\begin{array}{c}\text { Financeiras+ } \\
\text { bancos de } \\
\text { investimento }\end{array}$ \\
\hline 1968 & 11,08 & 8,20 & 1,36 & 0,77 & 0,21 & 1,61 & 3,72 \\
\hline 1969 & 11,99 & 7,46 & 1,51 & 1,12 & 0,26 & 2,30 & 3,81 \\
\hline 1970 & 12,56 & 7,12 & 2,21 & 1,42 & 0,30 & 3,06 & 3,98 \\
\hline 1971 & 13,54 & 6,76 & 2,50 & 1,52 & 0,43 & 3,59 & 5,20 \\
\hline 1972 & 15,01 & 7,32 & 2,93 & 1,84 & 0,66 & 3,94 & 6,14 \\
\hline 1973 & 15,69 & 7,91 & 3,48 & 2,39 & 0,74 & 4,14 & 7,40 \\
\hline
\end{tabular}

Fonte: IBGE/Anuário Estatístico do Brasil, 1980; Banco Central do Brasil/Relatório Anual. Elaboração própria.

O BNH, por sua vez, ao disponibilizar recursos para a construção civil, viabilizava a expansão de um setor intensivo em mão de obra. Entre 1967 e 1973, foram 948 mil unidades financiadas, das quais 513 mil no governo Médici (BRASIL, 1972 e 1974). O saldo das operações de crédito do BNH passou de 1,6\% do PIB em 1968 para 4,1\% em 1973 (tabela 4).

As financeiras e os bancos de investimento, por seu turno, também experimentariam um movimento de expansão. As primeiras, especializadas no financiamento ao consumo, perfaziam quase $89 \%$ desse subconjunto, ao passo que aos bancos de investimento caberiam as operações de subscrições de ações para finalidades distintas. Segundo a tabela 4, as operações de crédito oferecidas pelas financeiras e bancos de investimento passaram de 3,7\% do PIB em 1968 para 4\% em 1970 e $7,4 \%$ em 1973.

Finalmente, um último aspecto da política financeira deve ser mencionado. Em 1970, o Banco Central criou as Letras do Tesouro Nacional (LTN), títulos públicos destinados à operacionalização da política monetária. Desde 1969 a colocação líquida de ORTN superava o déficit público, indicando que aquele ano constituía um marco formal no qual a dívida pública assumia plenamente uma de suas funções primordiais: o financiamento do déficit público. Com as LTN, assumiria agora outra de suas funções históricas no capitalismo moderno: a operacionalização da política monetária, regulando a liquidez da economia. Em 1972, as LTN já representavam 33,6\% do estoque da dívida (PEDRAS, 2009).

\footnotetext{
${ }^{9}$ A soma dos percentuais não é compatível com a relação crédito total/PIB, porque para isso, seria necessário subtrair as operações entre as instituições financeiras. A tabela deve ser lida apenas como o tamanho relativo de cada subsetor do sistema financeiro.
} 


\subsection{A política de combate à inflação}

Como era de se esperar, Delfim manteve como diretriz básica de sua política anti-inflacionária o sistema de controle de preços executado por meio do Comitê Interministerial de Preços (CIP), criado no governo Costa e Silva. O CIP era presidido pelo Ministro da Indústria e Comércio, e era composto também pelos ministros da Fazenda, da Agricultura, e do Planejamento e Coordenação Geral. O CIP autorizava reajustes de preços para empresas e/ou setores previamente selecionados, mediante apresentação de planilhas de custo. As empresas que reajustassem seus preços sem obedecer essa sistemática perdiam acesso aos recursos dos bancos oficiais, e por essa razão tinham um forte estímulo a aderir a ela (MATA, 1980; BAER, KERSTENETZKY e VILLELA, 1973). Os índices de inflação, em queda desde 1968 - ano em que a política de controle de preços adquire caráter compulsório - atestam a eficácia da medida. Em 1973, a política de controle de preços foi fundamental para impedir que a forte elevação do preço do petróleo nos mercados internacionais fosse transmitida para os índices de inflação, já que nesse ano a trajetória dos índices de preços se descolou do deflator implícito do PIB, que acelerou em 10 pontos percentuais (tabela 5 ).$^{10}$

Tabela 5 - IGP-DI e deflator implícito do PIB, variação \%

\begin{tabular}{c|c|c|c|c|c|c|c}
\hline & 1967 & 1968 & 1969 & 1970 & 1971 & 1972 & 1973 \\
\hline IPC-Fipe & 25,33 & 25,22 & 22,58 & 17,46 & 20,60 & 17,46 & 13,96 \\
IGP-DI & 25,01 & 25,49 & 19,31 & 19,26 & 19,47 & 15,72 & 15,54 \\
IPA-EP & 22,00 & 24,20 & 19,27 & 18,49 & 21,44 & 15,94 & 15,53 \\
deflator implícito do PIB & 26,53 & 26,71 & 20,05 & 16,26 & 19,38 & 19,87 & 29,58 \\
\hline
\end{tabular}

Fonte: Ipeadata

Possivelmente, a política cambial contribuiu para isolar o sistema de preços brasileiro dos efeitos iniciais do choque do petróleo, já que em 1973 a taxa de câmbio se manteve praticamente estável. Em todo o governo Médici, a menor instabilidade da taxa de câmbio nominal constituiu componente importante para a política de controle da inflação, embora suas diretrizes fossem determinadas segundo os objetivos do comércio exterior brasileiro. Especialmente se comparado aos anos anteriores, durante o governo Médici foram registradas as menores taxas de desvalorização cambial (gráfico 1). Se por um lado a política cambial buscava

\footnotetext{
${ }^{10}$ Segundo Lago (1990), em 1973 a política de controle de preços vinha sendo burlada por empresas em vários setores, mas os índices de preços eram calculados segundo os preços estipulados pelo CIP e, portanto, não captavam essa nova situação.
} 
assegurar maior competitividade da produção doméstica por meio de reajustes da taxa de câmbio em intervalos de tempo menores, por outro, esses reajustes chegavam a ser inferiores à própria inflação doméstica.

Um terceiro componente também contribuiu para a maior estabilidade de preços durante o período: a política salarial. Tal como seus antecessores, Médici manteve a política salarial introduzida durante o governo Castello Branco, que consistia em reajustar os salários conforme os ganhos de produtividade adicionados à inflação esperada pelo governo. Como na prática a inflação verificada era sempre superior à esperada, o resultado foi a perda do poder de compra dos salários. O salário mínimo atingiu seu pior poder de compra em 1971, quando equivalia a apenas $68 \%$ do poder de compra médio de 1960 , sofrendo ligeira recuperação em 1973 (tabela 1). Desde o início da ditadura militar, a componente salarial não exercia qualquer pressão sobre a inflação.

Gráfico 1 - Variação da taxa de câmbio nominal, \%

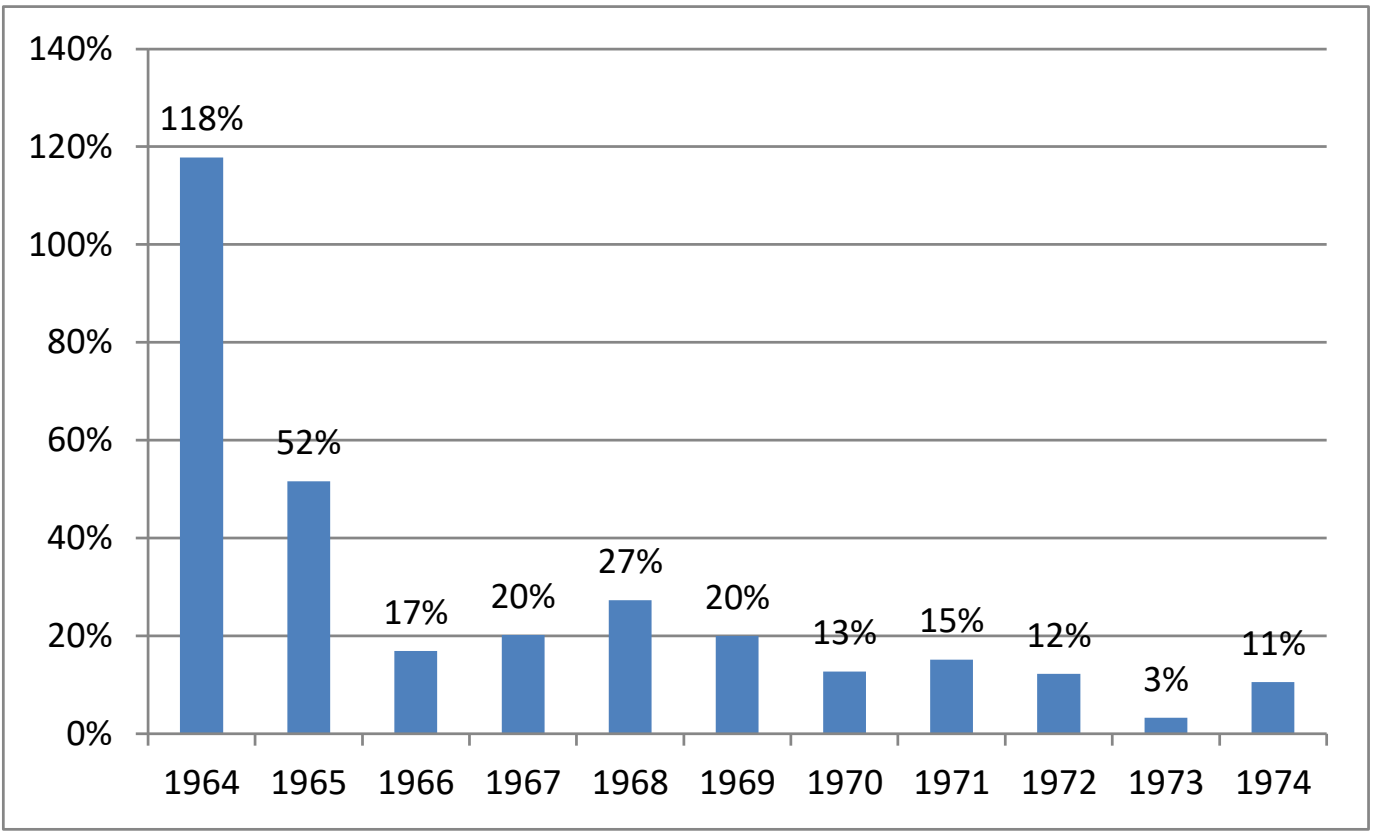

Fonte: IBGE, Estatísticas Históricas do Século XX, elaboração própria. 


\section{O setor externo}

A maior estabilidade da taxa de câmbio durante o governo Médici se explica, em grande medida, pelo cenário internacional. $O$ período coincide com a expansão do mercado de euromoedas, com o fim das regulamentações de Bretton Woods, e com o surgimento de inovações financeiras que permitiram aos bancos privados com atuação internacional expandir a oferta de recursos ao largo da regulamentação nacional ou internacional. ${ }^{11}$ Já a partir do final da década anterior o Brasil se colocava como receptáculo desses recursos, na modalidade de endividamento externo, mas esses fluxos se expandem sobremaneira a partir de 1971, quando o banco central norte-americano reverte o ciclo de contração de liquidez e inicia o processo de redução de suas taxas de juros (tabela 6). O estoque de dívida externa, que em 1968 era de US \$ 3,7 bilhões, atinge US\$ 5,3 bilhões em 1970 e US\$12,6 bilhões em 1973. O saldo total da conta capital e financeira, sempre superior ao déficit em transações correntes, garantia superávits crescentes no balanço de pagamentos e permitiu que o Banco Central já em 1970 dispusesse de um estoque de reservas internacionais no valor de US\$1,7 bilhão, e no valor US\$ 6,4 bilhões no último ano do governo Médici. Nesse momento, a dívida externa brasileira ainda era preponderantemente privada, e refletia um movimento das grandes empresas privadas nacionais e transnacionais em operação no território brasileiro em busca de recursos em melhores condições de taxas e prazos.

Por outro lado, o ritmo forte de crescimento da economia mundial permitia ao Brasil elevar suas exportações de forma consistente, em um movimento que refletia simultaneamente trajetórias mais favoráveis de preços e quantidades. $\mathrm{O}$ ritmo forte do crescimento doméstico também elevava as importações com rapidez, e nos anos de 1971 e 1972 a balança comercial registraria pequenos déficits. Entretanto, a deterioração do déficit em transações correntes não chegou a significar problema nesses anos, já que as condições internacionais permitiam financiamento em condições relativamente favoráveis até então. Afrouxada a restrição externa que historicamente interrompia os movimentos mais longos de expansão econômica no Brasil, o "milagre" seria, então caracterizado por este último elemento: a ausência de crises cambiais mesmo com a marcha acelerada com que o produto interno crescia.

\footnotetext{
${ }^{11}$ Ver, a este respeito: Eichengreen (2000), Serrano (2002) e Dathein (2005).
} 
Tabela 6 - Setor externo: dados selecionados

\begin{tabular}{|c|c|c|c|c|c|c|c|}
\hline & 1967 & 1968 & 1969 & 1970 & 1971 & 1972 & 1973 \\
\hline \multicolumn{8}{|c|}{ US\$ milhões } \\
\hline Transações correntes & -276 & -582 & -364 & -839 & -1630 & -1688 & -2085 \\
\hline Balança comercial & 213 & 26 & 318 & 232 & -344 & -241 & 7 \\
\hline Exportações & 1654 & 1881 & 2311 & 2739 & 2904 & 3991 & 6199 \\
\hline Importações & 1441 & 1855 & 1993 & 2507 & 3247 & 4232 & 6192 \\
\hline Serviços e rendas & -566 & -630 & -713 & -1092 & -1300 & $-145^{2}$ & -2119 \\
\hline $\begin{array}{l}\text { Conta capital e } \\
\text { financeira }\end{array}$ & 49 & 680 & 936 & 1281 & 2173 & 3793 & 4111 \\
\hline $\begin{array}{l}\text { Empréstimos e } \\
\text { financiamentos }\end{array}$ & 33 & 490 & 709 & 843 & 1699 & 3067 & 2410 \\
\hline Saldo do BP & -262 & 97 & 531 & 534 & 537 & 2538 & 2380 \\
\hline Dívida externa & 3.281 & 3.780 & 4.403 & 5.295 & 6.622 & $9 \cdot 521$ & 12.571 \\
\hline Reservas internac. & 198 & 257 & 656 & 1.187 & 1.723 & 4.123 & 6.416 \\
\hline \multicolumn{8}{|c|}{ Número índice, $1960=100$} \\
\hline $\begin{array}{c}\text { Termos de troca }(2006= \\
100)\end{array}$ & 102,65 & 97,62 & 102,21 & 112,37 & 105,90 & 106,36 & 118,97 \\
\hline Preço de exp. do café & 99,36 & 99,02 & 102,65 & 138,16 & 105,76 & 133,36 & 164,44 \\
\hline Preço das export. & 113,16 & 112,28 & 121,17 & 139,39 & 139,51 & 150,49 & 203,67 \\
\hline Quantum das export. & 114,88 & 131,91 & 150,18 & 154,72 & 163,90 & 208,82 & 239,66 \\
\hline Preço das import. & 110,44 & 115,02 & 118,55 & 124,04 & 131,73 & 141,49 & 171,20 \\
\hline Quantum das import. & 100,91 & 124,73 & 130,02 & 156,31 & 190,63 & 231,32 & 279,74 \\
\hline \multicolumn{8}{|l|}{ 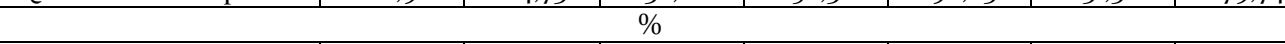 } \\
\hline Prime rate & 5,63 & 6,31 & 7,95 & 7,91 & 5,72 & 5,24 & 8,02 \\
\hline
\end{tabular}

Fonte: IBGE/Estatísticas Históricas do Século XX, Banco Central do Brasil, e Ipeadata. Elaboração própria

A forte expansão do endividamento externo durante o governo Médici permite caracterizar o período como de "crescimento com endividamento". A natureza desse endividamento externo, contudo, decorre muito mais das condições disponíveis nos mercados financeiros internacionais - em termos de taxas e prazos- do que das condições domésticas. A contrapartida do aumento do endividamento externo, na forma de aumento do estoque de reservas internacionais, revela que o crescimento do endividamento ocorreu de forma descolada do crescimento da absorção doméstica. Para Cruz (1983), o aumento do endividamento externo brasileiro refletiu muito mais uma inserção externa passiva, "capturada por um movimento geral do capital financeiro em busca de oportunidades de valorização" (p. 65) do que um movimento no qual os recursos externos financiariam a expansão do produto e da renda.

No plano doméstico, embora o sistema financeiro privado não reunisse as condições para prover as necessidades de financiamento do setor produtivo, especialmente as de longo prazo, as instituições públicas cumpriram esse papel, e o 
governo brasileiro usou fortemente da expansão de carga tributária e das chamadas contribuições parafiscais para disponibilizar recursos domésticos para essa finalidade. Como foi visto na seção 3.2, as principais agências oficiais de fomento BNDE, CEF, BB e BNH - expandiram suas operações, e o governo tornou viável essa expansão por meio dos fundos parafiscais: o FGTS, criado em 1966, e o PIS e o PASEP, criados em 1970. No caso específico do BNDE - voltado para o financiamento de longo prazo que expande a capacidade produtiva - embora as operações de crédito tenham se expandido, não se observou pressões sistemáticas sobre suas fontes de recursos, que durante o governo Médici registram a menor taxa de expansão (TAVARES ET AL., 2010), o que indica que os esquemas viabilizados durante os anos 1960 foram suficientes para sustentar suas operações durante os anos do "milagre" econômico. Essa enorme flexibilidade de expansão das fontes internas de financiamento contrasta com os argumentos de Cruz (1983) e Carneiro (2002), para quem a insuficiência do mercado financeiro doméstico teria induzido ao endividamento externo. ${ }^{12}$

Segundo Ferreira (2007: 45), durante os anos 1970 e 1973 o Brasil se endividou para acumular divisas. A autora elenca os argumentos pelos quais se desautoriza os diagnósticos de existência de hiatos de recursos e de divisas para explicar o aumento do endividamento externo. Em primeiro lugar, o financiamento às importações respondeu por parcela muito pequena (menos de $25 \%$ ) do endividamento externo total. Além disso, a poupança interna média se expandiu em $1 \%$ do PIB durante os anos Médici em comparação ao período anterior no qual não houve forte entrada de capital, o que desautoriza o diagnóstico de substituição de poupança interna por poupança externa. Em terceiro lugar, a maior parte do déficit em transações correntes foi provocada pelo déficit da conta de rendas. Mesmo o crescimento das importações, parcela do déficit em transações correntes intimamente relacionada com o ritmo da atividade econômica, foi em parte compensado com a expansão das exportações. Finalmente, o grau de utilização da capacidade produtiva na indústria oscilou entre $85 \%$ e $89 \%$ entre 1970 e 1973, chegando a $91 \%$ para a construção civil e a indústria de bens intermediários, o que comprova que "mesmo com a utilização da capacidade produtiva certamente acima do seu nível normal, havia uma folga razoável que no agregado seria capaz de sustentar maior demanda sem esgotamento da capacidade produtiva interna" (FERREIRA, 2007: 50).

\footnotetext{
${ }^{12}$ Ferreira (2007) também apontou a fragilidade deste argumento.
} 


\section{A questão distributiva}

No ano de 1972, a divulgação do censo demográfico com os dados referentes a 1970 pelo Instituto Brasileiro de Geografia e Estatística (IBGE) tornava evidente a outra face do "milagre" brasileiro. Os dados mostravam uma piora acentuada da distribuição de renda. O "milagre" festejado pela cúpula militar por ter dado a legitimidade econômica à ditadura militar, não se transbordava em melhores condições de vida para a maioria da população brasileira e abriu espaço para fortes críticas ao modelo econômico e às políticas implantadas desde 1964. O governo não censurou os dados que ele próprio produzira, mas tratou com rapidez de construir uma explicação oficial, contratando o economista Carlos Langoni.

A tabela 7 abaixo apresenta os principais dados que suscitaram a assim chamada controvérsia da distribuição da renda. A tabela apresenta a forma desigual com que os frutos do "milagre" se transbordavam por entre os distintos estratos de renda: enquanto a renda do decil mais rico subiu quase $67 \%$ ao longo da década, a do decil mais pobre cresceu somente $28 \%$; a renda relativa do decil mais rico cresceu $22 \%$, enquanto a do decil mais pobre decresceu $13 \%$; e somente o decil mais rico elevou sua participação na renda, de 39,6\% em 1960 para 47,8\% em 1970, enquanto todos os outros nove decis tiveram a sua participação na renda reduzida.

Tabela 7 - Brasil: comparação distribuição da renda, 1960-1970

\begin{tabular}{|c|c|c|c|c|c|c|c|c|c|}
\hline \multirow{2}{*}{$\begin{array}{c}\text { percenti } \\
1\end{array}$} & \multicolumn{3}{|c|}{ Percentagem da renda } & \multicolumn{3}{|c|}{ Renda média (Cr\$ de 1970 por mês) } & \multicolumn{3}{|c|}{ Renda relativa } \\
\hline & 1960 & 1970 & $\begin{array}{c}1960 / 1970 \\
(\%)\end{array}$ & 1960 & 1970 & $1960 / 1970(\%)$ & 1960 & 1970 & $\begin{array}{c}1960 / 1970 \\
(\%)\end{array}$ \\
\hline $10-$ & 1,17 & 1,11 & $-5,13$ & 25 & 32 & 28,00 & 0,12 & 0,11 & - \\
\hline 10 & 2,32 & 2,05 & $-11,64$ & 48 & 58 & 20,83 & 0,23 & 0,20 & $-13,04$ \\
\hline 10 & 3,42 & 2,97 & $-13,16$ & 71 & 84 & 18,31 & 0,34 & 0,30 & $-11,80$ \\
\hline 10 & 4,65 & 3,88 & $-16,55$ & 96 & 110 & 14,58 & 0,46 & 0,39 & $-15,22$ \\
\hline 10 & 6,15 & 4,90 & $-20,32$ & 127 & 139 & 9,45 & 0,61 & 0,50 & $-18,04$ \\
\hline 10 & 7,66 & 5,91 & $-22,75$ & 158 & 168 & 6,33 & 0,77 & 0,60 & $-28,33$ \\
\hline 10 & 9,41 & 7,37 & $-21,68$ & 195 & 210 & 7,69 & 0,94 & 0,74 & $-21,28$ \\
\hline 10 & 10,85 & 9,57 & $-11,80$ & 225 & 272 & 20,89 & 1,08 & 0,96 & $-10,20$ \\
\hline 10 & 14,69 & 14,45 & $-1,64$ & 305 & 411 & 34,75 & 1,48 & 1,46 & 1,35 \\
\hline $10+$ & $\begin{array}{c}39,6 \\
6\end{array}$ & $\begin{array}{c}47,7 \\
9\end{array}$ & 20,50 & 815 & 1360 & 66,87 & 3,95 & 4,82 & 22,02 \\
\hline $5+$ & $\begin{array}{c}27,6 \\
9\end{array}$ & $\begin{array}{c}34,8 \\
6\end{array}$ & 25,90 & 1131 & 1984 & 75,42 & 5,49 & 7,03 & 28,05 \\
\hline $1+$ & 12,11 & 14,57 & 20,32 & 2389 & 4147 & 73,59 & 11,60 & 14,70 & 26,72 \\
\hline $40-$ & 11,57 & 10,00 & $-13,57$ & 60 & 71 & 18,33 & 0,29 & 0,25 & $-13,80$ \\
\hline 20 & 13,81 & 10,81 & $-21,73$ & 142 & 153 & 7,74 & 0,68 & 0,55 & $-19,12$ \\
\hline $40+$ & $\begin{array}{c}74,6 \\
2\end{array}$ & 79,19 & 6,13 & 385 & 563 & 46,23 & 1,86 & 1,99 & 6,99 \\
\hline total & 100 & 100 & & 206 & 282 & 36,89 & & & \\
\hline
\end{tabular}

Fonte: Langoni (1973: 21) 
Tendo acesso a tabulações especiais que sequer estavam disponíveis a outros pesquisadores, ${ }^{13}$ Carlos Langoni construiu a retórica oficial à luz de um modelo econométrico por meio do qual tentaria atribuir pesos aos diferentes fatores causadores da piora da desigualdade. Seu modelo foi construído à luz da teoria marginalista da distribuição - a teoria neoclássica - que atribui o salário real à produtividade marginal do trabalho, em que essa variável seria explicada pelo capital humano, traduzido em anos de escolaridade e de idade. Para Langoni, esses são os principais fatores explicativos da piora da distribuição de renda ocorrida durante a década de 196o. Segundo Langoni, a natureza do estágio de desenvolvimento em que se encontrava a economia brasileira naquele período, requerendo investimentos em setores intensivos em tecnologia, explicaria, segundo ele, a maior demanda por mão de obra de maior qualificação, que é também melhor remunerada, mas cuja disponibilidade era reduzida. $\mathrm{O}$ estágio do processo de desenvolvimento econômico brasileiro, com transferência de mão-deobra do meio rural para o meio urbano, reforçaria as desigualdades, já que a baixa qualificação dessa mão-de-obra a impossibilitaria de acessar os empregos com maiores remunerações. Em suma, a desigualdade seria explicada por uma combinação entre a estrutura ocupacional (composição entre setores, meio urbano ou rural) e qualificação da mão de obra - incluindo a idade, que também é uma proxy da qualificação).

Essa desigualdade, contudo, seria transitória: segundo Langoni, a melhor remuneração dos empregos que exigem maior qualificação estimularia o maior investimento em capital humano, ou seja, em qualificação da mão-de-obra. Esse estímulo ocorreria ou por maior pressão da sociedade por maior investimento público em educação, mas também por parte das empresas, desejosas em reduzir a escassez de mão-de-obra qualificada. A correção da desigualdade, contudo, não poderia prescindir do processo de desenvolvimento econômico, sem o que os mecanismos de correção das desigualdades não estariam aptos a atuar. Em outras palavras, Langoni realizava um esforço em explicar porque o processo de desenvolvimento econômico ainda não se transbordara em melhoria da distribuição da renda - mas seria uma questão de tempo, desde que não se interrompesse a trajetória virtuosa em que a economia brasileira se encontrava. Segundo Malta (2010: 208), o trabalho de Langoni14 tentava dotar de "cientificidade", com pitadas de "culinária econômica", a famosa frase do Ministro

\footnotetext{
${ }^{13}$ Segundo Malta (2010), além dos dados referentes ao Censo de 1970, Langoni teve acesso aos dados do imposto de renda e da Lei dos $2 / 3$ vinculada à Consolidação das Leis do Trabalho (CLT), o que lhe assegurou dados de rendas individuais. Anos mais tarde, foi garantido o acesso a esses dados por outros pesquisadores, exceto os do IR, de modo que alguns resultados de Langoni jamais puderam ser replicados pela comunidade científica.

${ }^{14}$ Além de Langoni, outros economistas também contribuíram para a retórica oficial, como Roberto Campos e Mário Henrique Simonsen.
} 
Delfim Netto, segundo a qual é necessário primeiro fazer o bolo crescer para depois distribuir.

Diversas foram as críticas ao discurso oficial, e o debate pode ser lido em Barone, Bastos e Mattos (2015) e em Malta (2010). A crítica de Rodolfo Hoffmann se refere à especificação do modelo econométrico de Langoni, que se ateve às rendas do trabalho. Pedro Malan,Jonh Wells, e Albert Fischlow destacaram que ainda que no modelo de Langoni uma parcela grande da desigualdade fosse explicada pela escolaridade, essa parcela não era majoritária. Outro padrão de críticas destaca o papel decisivo da política econômica em curso depois de 1964, e das reformas do governo Castello Branco. O sistema tributário oriundo das reformas orquestradas por Roberto Campos e Octávio Bulhões, respectivamente os ministros do Planejamento e da Fazenda daquele governo, aprofundou o seu caráter regressivo, porque foi concentrado em impostos indiretos. Os poucos elementos de progressividade, introduzidos no imposto de renda, foram, parcial ou integralmente compensados por isenções dados no âmbito de pessoas jurídicas como parte integrante das políticas de estímulo produtivo - e de pessoas físicas como parte das políticas destinadas a estimular o mercado de capitais. Nesse caso específico, as isenções do imposto de renda foram destinadas aos extratos de renda mais elevada da sociedade brasileira.

Mas é na política salarial que reside o aspecto mais concentrador do período pós 1964. A extinção da estabilidade no emprego, somada ao caráter autoritário do regime militar, que interveio nos sindicatos e cassou os direitos políticos das lideranças mais combativas - quando não as prendeu, torturou ou matou provocou um enfraquecimento do seu poder de barganha, sobretudo para enfrentar a regra de reajuste salarial que impunha severas perdas do poder aquisitivo do salário mínimo e dos salários mais próximos a esse patamar.

Além disso, outros elementos da política especificamente adotada após 1967 reforçaram o caráter concentrador. Segundo Singer (1976), a política de controle de preços favoreceu a concentração de empresas especialmente setores monitorados pelo CIP, pois o órgão tomava como parâmetros as estruturas de custos das grandes empresas, prejudicando empresas que, com escalas de produção menores, não conseguiam adequar seus custos aos padrões das firmas oligopolistas. Nesse caso, somente as margens de lucro dos grandes produtores eram preservadas. Enquanto as grandes firmas em diversos setores produtivos eram autorizadas a elevar seus preços na medida dos aumentos de seus custos, e os bancos eram beneficiados com redução de seus custos de operação para evitar a compressão de suas margens de lucro pelo tabelamento de juros de suas operações ativas, os trabalhadores não podiam dar-se ao luxo de recompor as perdas inflacionárias. 
6. A distribuição da renda, a política macro e as causas do "milagre": uma contribuição ao debate

O debate das causas da má distribuição de renda durante o milagre segue inconcluso. Outro debate, contudo, ainda merece destaque e diz respeito à funcionalidade da piora da distribuição da renda ao modelo econômico inaugurado durante o "milagre". Essa interpretação foi oferecida inicialmente em 1970 por Maria da Conceição Tavares e José Serra (TAVARES \& SERRA, 1979), e estimulou interpretações posteriores, como a de Furtado (1972, 1983) e Mendonça (1988), entre outros autores. Segundo tal interpretação, a concentração de renda exerceu papel funcional ao novo padrão de acumulação inaugurado após 1964, no qual os setores líderes consistem na (ou estão associados à) produção de bens de alto valor unitário (como os de consumo durável), cuja viabilidade requer uma escala de mercado que foi assegurada por um processo dinâmico de concentração de renda. Este, por sua vez, transferiu rendas das camadas mais baixas para o topo da pirâmide, por medidas diversas, entre as quais a abertura do leque salarial, garantindo que o topo da pirâmide tivesse tamanho compatível com a escala de mercado requerida pelos setores líderes do novo padrão de acumulação. Por outro lado, o arrocho salarial na base da pirâmide reduziu o custo de produção de forma generalizada, permitindo elevação dos lucros, a partir dos quais parte do investimento poderia ser financiado.

Mas a simples concentração de renda ainda não seria suficiente para engendrar taxas tão robustas de crescimento econômico. Nesse esquema, outro elemento seria decisivo para viabilizar o avanço do processo de acumulação: o crédito ao consumo, oferecido pelas financeiras criadas nas reformas do governo Castello, possibilitando que as camadas de rendas médias tivessem acesso à parte desses bens sem que para isso fosse necessário engendrar um complexo processo de distribuição de renda. Além disso, o financiamento ao investimento também complementaria os recursos internos às firmas, já expandidos pela maior massa de lucros acima descrita. Nesses dois casos, as reformas financeiras cumpriram papel relevante.

As exportações finalizariam o esquema: os mercados externos se adicionariam ao mercado doméstico e contribuiriam para dar escala e lucratividade aos setores líderes, quando a concentração de renda ainda fosse empecilho.

Assim, o conjunto de reformas do governo Castello teria viabilizado a concentração de renda, cuja funcionalidade residia na formação do mercado específico em tamanho suficiente para dar escala e viabilidade para os novos setores líderes, somado à possibilidade de financiamento desses bens. Mendonça (1996: 75), diante da concentração de renda e do arrocho salarial, ocorridos 
durante o período, cita Francisco de Oliveira: "milagre seria se não ocorresse o milagre".

Essa chave interpretativa assume um viés crítico tanto das reformas do governo Castello como do conjunto da política econômica executada no período do assim chamado "milagre" econômico, exatamente pelo aspecto desigual que assumiu. Esse esforço de compreender os determinantes do "milagre" deve ser lido no contexto em que o desempenho da economia brasileira iniciado em 1968 contrapôs factualmente as previsões feitas no início dos anos 1960 pelos economistas da tradição heterodoxa brasileira, entre eles o próprio Furtado (FURTADO, 1968). Segundo essa tradição, a crise do início dos anos 1960 tinha caráter estrutural, associado justamente à má distribuição de renda que se observava naquele estágio, e que impediria que o processo de acumulação produtiva avançasse exatamente porque os próximos setores a substituir importação eram os produtores de bens duráveis, cujo valor unitário mais elevado exigia uma escala de mercado incompatível com as condições que a má distribuição da renda no Brasil impunha. A tradição heterodoxa brasileira era pessimista e apontava para um cenário no qual a viabilidade do capitalismo brasileiro requeria reformas que melhorassem a distribuição da renda, sem o que a longa estagnação seria inevitável (SALM, 2010, BASTOS \& GALARZA, 2009).

Ocorre que os governos Costa e Silva e Médici provaram o contrário: com níveis ainda maiores de concentração de renda, seus governos obtiveram uma dinâmica macroeconômica impensável para a tradição heterodoxa brasileira, que por essa razão teve de buscar uma explicação plausível, e a encontrou nas reformas do governo Castello. Essa chave interpretativa coloca as reformas no centro da sua relação de causalidade, mas os mecanismos que operam na distribuição da renda seriam essenciais para explicar a dinâmica econômica posterior.

Essa chave interpretativa dá pouca centralidade às modificações ocorridas na política macroeconômica - que naqueles anos não ocupava papel central no debate, salvo em situações muito específicas, como no debate sobre a inflação. Pois foi exatamente para debater a política macroeconômica que os autores de tradição ortodoxa se apropriaram dessa chave interpretativa, só que desprezando o aspecto distributivo, ou atribuindo a ele um papel meramente secundário, senão menor.

Como Araujo (2017) apontou, o governo Castello Branco realizou políticas monetária e fiscal bastante apertadas e impopulares, obtendo um desempenho macroeconômico bastante fraco, que inclusive punha em xeque a legitimidade do governo que assumiu em abril de 1964 por meio de um golpe de estado. As políticas heterodoxas executadas após o governo Costa e Silva obtiveram resultados muito mais promissores e colocaram a ortodoxia na defensiva, a quem não restou outra opção senão construir uma narrativa que fosse minimamente favorável às políticas que defendia. Segundo essa narrativa, os resultados do governo Castello 
não podem ser avaliados estritamente no interregno $1964-67$, mas sim pelo legado que deixaram - no caso, instituições e políticas que não só foram imprescindíveis, como foram as principais causadoras do desempenho obtido na fase do "milagre". Lago (1990) destaca a restauração da credibilidade na condução da política econômica. Cysne (1993) faz uma analogia rural, defendendo que os governos Costa e Silva e Médici colheram "com abundância" (p. 205) porque o plantio foi bem feito. Veloso, Vilella e Giambiagi (2007: 33) também recorreram à analogia semelhante, alegando que Castello "plantou muito para colher pouco". Pastore e Pinotti (2007: 20) argumentam que as reformas "não esgotaram seus efeitos nos três anos do governo Castello Branco, determinando um novo regime econômico que influenciou as políticas econômicas da década de 1970". Baer (1988) trata o período iniciado em 1964 até 1973 como linear e de continuidade, em seção intitulada "Políticas econômicas desde 1964", assumindo a causalidade das reformas para explicar o milagre. Admite o crescimento do gasto público a partir do governo Costa e Silva, especialmente do investimento público, mas também compartilha o mérito com Castello, argumentando que em seu governo foram encomendados estudos setoriais básicos em vários setores, mas a defasagem de tempo entre os estudos de viabilidade e a execução fizeram com que os resultados fossem sentidos somente no final da década.

Ao desprezar ou minimizar o aspecto distributivo e centrar-se no aspecto macroeconômico, essa chave de leitura assume um caráter apologético das reformas. Mais ainda, ao desprezar a guinada na política macroeconômica, praticamente atribuem o "milagre" como um resultado natural das reformas de Castello Branco e de seus ortodoxos ministros Roberto Campos e Octavio Bulhões, assessorados por Mario Henrique Simonsen. Mas, como alerta Araujo (2017): a intenção não era reabilitar Castello Branco, mas seus economistas, bem como as medidas ortodoxas que executaram. ${ }^{15}$

\footnotetext{
${ }^{15}$ Resende (1990) fez um esforço contrário, mas com o mesmo objetivo de reabilitar a ortodoxia: como os resultados do governo Castello foram decepcionantes, procurou caracterizar como heterodoxas as políticas de Campos e Bulhões. Primeiro, no plano das intenções, já que parte do diagnóstico de inflação embutido no PAEG utilizava-se do conflito distributivo, uma contribuição teórica tipicamente keynesiana, e cujo combate se dá por meio de políticas de rendas - no caso, um arrocho salarial, já que o conflito tinha origem no aumento dos salários reais acima dos ganhos de produtividade. Ressalte-se que o PAEG assumia que o déficit público e a emissão monetária também eram fatores causadores da inflação, em um mecanismo tipicamente ortodoxo, cujas proposições de políticas iam perfeitamente ao encontro da ortodoxia econômica e das medidas elencadas no Paeg. O segundo argumento de Resende está no plano da execução da política monetária: as metas de expansão da base monetária foram, em geral, frustradas. O motivo foi o ingresso de capitais externos acima das expectativas. Como não era possível realizar as operações de esterilização, já que a dívida pública ainda não havia assumido sua clássica função de controlar a liquidez, o resultado foi uma expansão de Mo acima das projeções da equipe econômica. Some-se a isso um relaxamento da política fiscal no ano de 1965, e pronto! O Paeg se tornou heterodoxo.
} 
Contudo, a política macroeconômica inaugurada pós 1967 não tem praticamente qualquer elemento consistente com as proposições ortodoxas. Especificamente durante o governo Médici, o que se observa é que as instituições foram, inclusive, reformuladas para padrões que escapam completamente do padrão ortodoxo. Senão vejamos. A política fiscal foi manejada sob os auspícios da expansão do gasto em todos os anos, e a taxas crescentes; o equilíbrio orçamentário, embora obtido, não era uma obsessão por parte do governo. Por outro lado, a execução orçamentária escamoteava outros gastos realizados por meio do assim chamado orçamento monetário. Nesse sentido, Médici não só dava continuidade à expansão fiscal iniciada no governo Costa e Silva, como aprimorava os instrumentos para intensificar esse padrão de política, escamoteando parte do gasto público no orçamento monetário, por meio de um "aprimoramento" institucional que causaria horror (e realmente causou) a qualquer economista de tradição ortodoxa.

Na política financeira, o governo Médici tomou medidas - em caráter de continuidade e aprimoramento daquelas iniciadas por Costa e Silva - que expandiram o crédito por todos os meios possíveis, públicos e privados. Entre os públicos é notória a expansão das instituições oficiais de fomento, como o BNDE e o $\mathrm{BNH}$, todos criados por governos que o antecederam. E prosseguiu, por meio dos fundos PIS e Pasep, a diretriz de criar fundos parafiscais para financiar os grandes projetos. Já o crédito privado sofreu forte intervenção por meio da política de tabelamento dos juros. Para os propósitos deste artigo, nunca é redundante lembrar que medidas dessa natureza se opõem radicalmente ao receituário ortodoxo.

A inflação, por sua vez, seguia controlada por meio de políticas de controle administrativo dos preços, outro elemento de horripilar qualquer economista ortodoxo.

Na política referente ao setor externo, os elementos que aproximam Médici de Costa e Silva e os afastam de Castello decorrem muito mais da conjuntura internacional, que se modifica desde o final dos anos 1960. A maior integração com a economia internacional constitui diretriz comum aos três governos. As minidesvalorizações cambiais, iniciadas no governo Costa e Silva, seguiram no governo Médici.

Finalmente, a política salarial constituiria o último elemento também comum aos três governos.

O governo Médici, assim, completou seis anos de políticas macroeconômicas com viés francamente expansivos, em caráter completamente distinto daquele inaugurado por Castello Branco. Ainda que as reformas de 1964-67 tivessem viabilizado alguns instrumentos importantes para o ciclo expansivo iniciado em 
1968, a mudança no sentido de sua condução foi primordial para os resultados alcançados.

Referências

ARAUJO, V. L. (2017) A política macroeconômica do governo Costa e Silva (1967-1969). Anais do XXII Encontro Nacional de Economia Política, Campinas. XXII Encontro Nacional de Economia Política.

BAER, W. (1988) A industrialização e o desenvolvimento econômico do Brasil. Rio de Janeiro: Editora da Fundação Getúlio Vargas.

BAER, W.; KERSTENETZKY, I.; VILLELA, A. V. (1973). As modificações do papel do estado na economia brasileira. Pesquisa e Planejamento Econômico, vol. 3 (4), pp. 883 a 912.

BANCO DO BRASIL (2010) Banco do Brasil: 200 anos, 1964-20o8, livro 2. Belo Horizonte: Del Rey, Fazenda Comunicação \& Marketing.

BARONE, R. S.; BASTOS, P. P. Z.; MATTOS, F. A. M. (2015) A distribuição de renda durante o "milagre econômico" brasileiro: um balanço da controvérsia. Texto Para Discussão, IE/Unicamp, no 251.

BASTOS, C.P.M. e GALARZA, J. O debate do desenvolvimento na tradição heterodoxa brasileira. Revista de Economia Contemporânea (UFRJ), v.13, n.2, maio-ago 2009.

BRASIL. BANCO CENTRAL DO BRASIL (BCB) (1972) Banco Central do Brasil: Relatório Anual, Brasília, vol. 10, ㄲo 3 .

BRASIL. BANCO CENTRAL DO BRASIL (BCB) (1974) Banco Central do Brasil: Relatório Anual, Brasília, vol. 10, ㄲo 3 .

BRASIL. PRESIDÊNCIA DA REPÚBLICA (1971). Plano Nacional de Desenvolvimento. S.l.

CARNEIRO, R. (2002), Desenvolvimento em Crise - A economia brasileira no último quarto do século XX, São Paulo, Editora UNESP, IE - Unicamp.

CARVALHO, L. F. C. (2008) Equilíbrio fiscal e política econômica keynesiana. Revista Análise Econômica, Porto Alegre, vol. 26, n. 50, pp. 7-25.

CARVALHO, L. F. C. (1999). Políticas econômicas para economias monetárias. In: LIMA, G. T.; SICSÚ, J.; PAULA, L. F. Macroeconomia moderna: Keynes e a economia contemporânea. Rio de Janeiro: Campus. 
CINTRA, M. A. M. (2009) Crédito público e desenvolvimento econômico: a experiência brasileira. In: FERREIRA, F. M. R.; MEIRELLES, B. B. Ensaios sobre economia financeira. Rio de Janeiro: BNDES.

CORAZZA, G. (2006) O Banco Central do Brasil: evolução histórica e institucional. Perspectiva Econômica, v. 2, nº 1, pp. 1-23, jan/jul.

COSTA, F. N. (2012) Brasil dos bancos. São Paulo: Edusp.

CRUZ, P. D. (1983) Notas sobre o endividamento externo brasileiro nos anos setenta. In: BELluZZO, L. G. M. \& COUTINHO, R. (Org.) Desenvolvimento capitalista no Brasil: ensaios sobre a crise, vol. 2. São Paulo: Brasiliense.

CYSNE, Rubens Penha. A economia brasileira no período militar. Estudos Econômicos, São Paulo, vol. 23, no 2, pp. 185-226, mai/ago 1993.

DATHEIN, R. (2005) Sistema monetário internacional e globalização financeira nos sessenta anos de Bretton Woods. Revista da Sociedade Brasileira de Economia Política, no 16, pp. 51-73.

EICHENGREEN, B. (200o) A globalização do capital: uma história do Sistema Monetário Internacional. São Paulo, Editora 34.

FERREIRA, L. (2007) Uma releitura do processo de endividamento externo e interno nos anos 1970 e 1980. Niterói: Dissertação de Mestrado em Ciências Econômicas, Universidade Federal Fluminense.

FURTADO, C. (1968) Subdesenvolvimento e estagnação na América Latina. Rio de Janeiro: Civilização Brasileira, cap. 3.

FURTADO, C. (1972). Análise do 'modelo’ brasileiro. Rio de Janeiro: Civilização Brasileira.

FURTADO, C. (1973) O Brasil pós-“milagre”. Rio de Janeiro: Paz e Terra.

GENTIL, D.; HERMANN, J. (2015) A política fiscal do primeiro governo Dilma Rousseff: ortodoxia $\mathrm{e}$ retrocesso. http://www.ie.ufrj.br/images/pesquisa/pesquisa/textos_sem_peq/texto1711.pdf

GOBETTI, S. (2008) Tópicos sobre a política fiscal e o ajuste fiscal no Brasil. Brasília: Universidade de Brasília, Tese de Doutorado em Economia. 
HORTA, M. H. (1981) Atribuições das autoridades monetárias no Brasil e formulação do Orçamento Monetário. Brasília: Instituto de Pesquisa Econômica Aplicada/IPEA, Texto para Discussão no 36 .

KEYNES, J. M. (1936 [1996]) A teoria geral do emprego, do juro e da moeda. São Paulo: Editora Nova Cultural.

LAGO, L. A. C. (1990) A retomada do crescimento e as distorções do 'milagre': 1967-1973. In: ABREU, M. P. (Org) A ordem do progresso: cem anos de política econômica republicana, 1889-1989. Rio de Janeiro: Campus.

LANGONI, C. G. (1973) Distribuição da renda e desenvolvimento econômico do Brasil. Rio de Janeiro: Expressão e Cultura.

LOLOYAN, A. J. (1980). Um estudo do Fundo PIS/PASEP. Campinas: Dissertação de Mestrado, Departamento de Economia e Planejamento Econômico do Instituto de Filosofia e Ciências Humanas da Universidade Estadual de Campinas.

LOPREATO, F. L. C. (2002) O colapso das finanças estaduais e a crise da federação. São Paulo: Editora UNESP/IE-Unicamp.

MACARINI, J. P. (2005) A política econômica do governo Médici: 1970-1973. Nova Economia, Belo Horizonte, vol. 15 (3), pp. 53-92. DOI: https://doi.org/10.159o/So10363512005000300003

MACARINI, J. P. (2007) A política bancária do regime militar: o projeto de conglomerado (1967-1973). Economia e Sociedade, Campinas, v. 16, n. 3.

MALTA, M. M. (2010) Sensos do contraste: o debate distributivo no "milagre". In: (Org.). Ecos do Desenvolvimento: uma história do pensamento econômico brasileiro. Rio de Janeiro: IPEA/UFRJ, 2010.

MATA, M. (1980) Controles de preços na economia brasileira: aspectos institucionais e resultados. Pesquisa e Planejamento Econômico, vol. 10 (3), pp. 911-954.

MENDONÇA, S. R. (1996) A industrialização brasileira. São Paulo: Moderna.

MENDONÇA, S. R. (1988) Estado e economia no Brasil: opções de desenvolvimento. Rio de Janeiro: Graal. 
OLIVEIRA, F. A. (2013) Tributação e fisco no Brasil: avanços e retrocessos entre 1964 e 2010. In: CARDOSO JR. J. C.; BERCOVICI, G. (Orgs.) República, democracia e desenvolvimento: contribuições ao Estado brasileiro contemporâneo. Brasília, Ipea.

PASTORE, A. C.; PINOTTI, M. C. (2007) O Paeg e as políticas econômicas dos anos 196o e 1970. In: MOURA, A. (Org.) Paeg e Real: dois planos que mudaram a economia brasileira. Rio de Janeiro: Editora FGV.

PEDRAS, G. B. V. (2009) História da dívida pública no Brasil: de 1964 até os dias atuais. In: SILVA, A. C.; CARVALHO, L. O.; MEDEIROS, O. L. Dívida Pública: a experiência brasileira. Brasília: Secretaria do Tesouro Nacional: Banco Mundial.

RESENDE, A. L. (1990) Estabilização e reforma: 1964-1967. In: ABREU, M. P. (Org.) A ordem do progresso: cem anos de política econômica republicana, 1889-1989. Rio de Janeiro: Campus.

SALM, Cláudio. O debate sobre a tendência à estagnação. In: MALTA, Maria Mello (Org.) Ecos do Desenvolvimento: uma história do pensamento econômico brasileiro. Rio de Janeiro: IPEA/UFRJ, 2010.

SINGER, P. (1976) A crise do "milagre”. Interpretação crítica da economia brasileira. Rio de Janeiro: Paz e Terra.

SKIDMORE, T. (1988) Brasil: de Castelo a Tancredo. Rio de Janeiro: Paz e Terra.

TAVARES, M. C. T. \& SERRA, J. (1979) Além da estagnação. In: TAVARES, M. C. Da substituição de Importações ao capitalismo financeiro, ensaios sobre a economia brasileira, Zahar, Rio de Janeiro.

TAVARES, M. da C. et al. (2010) O papel do BNDE na industrialização do Brasil: os anos dourados do desenvolvimentismo, 1952-1980. Memórias do Desenvolvimento, v. 4 (4).

VELOSO, F. A.; VILlELA, A.; GIAMBIAGI, F. (2007) Determinantes do "milagre" econômico brasileiro (1968-1973): uma análise empírica. Brasília: Instituto de Pesquisa Econômica Aplicada, Texto para Discussão noㅜ 1273.

Recebido em 01.08.17

Aprovado em 11.05.18 